\title{
Comparative study on zinc oxide nanocrystals synthesized by two precipitation methods
}

\author{
(Estudo comparativo em nanocristais de óxido de zinco \\ sintetizados por dois métodos de precipitação)
}

\author{
M.R.Bodke ${ }^{1}$, Y. Purushotham ${ }^{2}$, B. N. Dole ${ }^{I^{*}}$ \\ ${ }^{I}$ Advanced Materials Research Laboratory, Department of Physics, Dr. Babasaheb Ambedkar Marathwada \\ University, Aurangabad-431 004, India \\ ${ }^{2}$ Centre for Materials for Electronics Technology, IDA Phase III, Cherlapally, Hyderabad-500 051, India \\ *dolebn_phys@yahoo.in
}

\begin{abstract}
Zinc oxide nanocrystals were synthesized by two precipitation methods successfully. The nanocrystals prepared via method I (zinc acetate dihydrate precipitation with $\mathrm{KOH})$ were smaller in crystallite size $(\sim 20 \mathrm{~nm})$ as compared to method II (zinc nitrate hexahydrate precipitation with $N, N$-dimethylformamide, $\sim 33 \mathrm{~nm}$ ). FTIR technique was used to study chemical bonding; SEM and EDS were used to study morphology and chemical compositions. Number of concentric rings corresponding to diffraction peaks was higher in SAED pattern for $\mathrm{ZnO}$ nanocrystals synthesized by method I than II. Variation in the energy band gap as a function of particle size was determined using absorption spectra from UV-vis-NIR spectrophotometer. Redshift was observed in the energy band gap of sample prepared via method II. Particle size and the structure of the nanocrystals were analysed by transmission electron microscope (TEM). From TEM study, it was found that the average particle size of method I nanocrystals was smaller compared to method II nanocrystals. Magnetic study was carried out using VSM. Ferromagnetism like contribution was observed for the sample prepared by method II. Keywords: $\mathrm{ZnO}$ nanocrystals, precipitation, redshift, crystallite size, energy band gap.
\end{abstract}

Resumo

Nanocristais de óxido de zinco foram sintetizados por dois métodos de precipitação. Os nanocristais preparados pelo método I (precipitação de acetato de zinco di-hidratado com $\mathrm{KOH}$ ) foram menores em tamanho de cristalito ( 20 nm) em comparação com o método II (precipitação de nitrato de zinco hexa-hidratado com $N, N$-dimetilformamida, $\sim 33 \mathrm{~nm}$ ). A técnica FTIR foi utilizada para estudar a ligação química; MEV e EDS foram utilizados para estudar a morfologia e composição química. O número de anéis concêntricos correspondentes aos picos de difração foi maior no padrão SAED para nanocristalinos de ZnO sintetizados pelo método I do que II. A variação da banda de energia proibida em função do tamanho de partícula foi determinada usando espectros de absorção UV-vis-NIR. Deslocamento para o vermelho foi observado na banda proibida da amostra preparada pelo método II. O tamanho de partícula e a estrutura dos nanocristais foram analisados por microscópio eletrônico de transmissão (MET). A partir do estudo de MET, verificou-se que o tamanho médio de partícula dos nanocristais do método I foi menor em comparação com os nanocristais do método II. O estudo magnético foi realizado com VSM. Contribuição do tipo ferromagnetismo foi observada para a amostra preparada pelo método II.

Palavras-chave: nanocristais de $\mathrm{ZnO}$, precipitação, deslocamento para o vermelho, tamanho de cristalito, banda de energia proibida .

\section{INTRODUCTION}

Zinc oxide has wide range of applications in varistors, pigment in paints and sunscreen for the prevention of sunburn due to its ability to absorb ultraviolet light. $\mathrm{ZnO}$ is most promising n-type oxide semiconductor with wide band gap of $3.37 \mathrm{eV}$ at room temperature in bulk form, large exciton binding energy $(60 \mathrm{meV})$, which is 2.4 times the effective thermal energy $(25 \mathrm{meV})$, large saturation velocity $\left(3 \cdot 2 \cdot 10^{7} \mathrm{~cm} / \mathrm{s}\right)$ and high break down voltage $[1,2]$. $\mathrm{ZnO}$ crystallizes in three forms: (i) hexagonal, (ii) cubic zinc blende, and (iii) cubic rock salt. Hexagonal (wurtzite) is the main stable crystal structure of $\mathrm{ZnO}$ at room temperature
[3]. $\mathrm{ZnO}$ nanostructures such as nanocrystals, nanorods, nanobelts, nanotubes and especially nanowires are attracting more and more attention due to their vital electronic, optical and magnetic properties as well as unique morphology for both interconnects and functional units in fabricating nanodevices [4-7]. Particularly, spintronics devices such as spin valve transistors, non-volatile memory, logic devices, ultrafast optical switches and optical isolators have stimulated great passions of many researchers for introducing room temperature ferromagnetism in nanostructured $\mathrm{ZnO}$ materials $[8,9]$.

Various synthesis methods have been used for the preparation of $\mathrm{ZnO}$ nanostructures such as vapour-liquid- 
solid method, reaction vapour deposition, physical vapour deposition, pulsed laser deposition, thermal evaporation and chemical solution routes, like sol-gel, precipitation and hydrothermal methods [10, 11]. Among these synthesis routes, chemical solution routes are cost effective, convenient and have general advantages such as super uniformity and high yield of nanocrystals [12].

In the present study, $\mathrm{ZnO}$ nanocrystals were synthesized by two chemical precipitation routes, then compared the quality of the samples by XRD, optical properties, TEM, FTIR, EDS and VSM studies. Samples prepared by zinc acetate dihydrate precipitation with $\mathrm{KOH}$ carried higher quality than zinc nitrate hexahydrate precipitation with $\mathrm{N}, \mathrm{N}$-dimethylformamide. Results of such an investigation were elucidated qualitatively in this paper.

\section{MATERIALS AND METHODS}

Precipitation method I - zinc acetate dihydrate precipitation with $\mathrm{KOH}$ : the starting materials used for the synthesis of $\mathrm{ZnO}$ nanocrystals were zinc acetate dihydrate and $\mathrm{KOH}$ with $99 \%$ purity. The appropriate amounts of zinc acetate and potassium hydroxide were dissolved separately in $100 \mathrm{~mL}$ methanol and stirred at room temperature for $2 \mathrm{~h}$. After fully dissolved, potassium hydroxide solution was added drop-wise with vigorous stirring resulting in a light sky-blue coloured precipitate. The precipitate was stirred again for $2 \mathrm{~h}$ to get homogeneous particle size. The precipitate was collected and washed several times by methanol followed by deionised water. Finally, $\mathrm{ZnO}$ nanocrystals were obtained after calcining the precursor at $450{ }^{\circ} \mathrm{C}$ for $12 \mathrm{~h}$.

Precipitation method II - zinc nitrate hexahydrate precipitation with $\mathrm{N}, \mathrm{N}$-dimethylformamide: chemicals used in this method were zinc nitrate hexahydrate and $\mathrm{N}, \mathrm{N}$-dimethylformamide with $99 \%$ purity. Zinc nitrate hexahydrate of appropriate weight was dissolved in $50 \mathrm{~mL}$ $\mathrm{N}, \mathrm{N}$-dimethylformamide and stirred with a magnetic stirrer for $1 \mathrm{~h}$ at $40{ }^{\circ} \mathrm{C}$. The solution was heated for $1 \mathrm{~h}$ at $150{ }^{\circ} \mathrm{C}$ for the formation of sol. The product was dried at $150{ }^{\circ} \mathrm{C}$ to form nanopowder and then ground for $15 \mathrm{~min}$ and calcined at $450{ }^{\circ} \mathrm{C}$ for $8 \mathrm{~h}$ to obtain $\mathrm{ZnO}$ nanocrystals.

Crystal structure of $\mathrm{ZnO}$ was determined by $\mathrm{X}$-ray diffraction (XRD, Panalytical, PW-3710) with $\mathrm{CuK} \alpha$ radiation $(\lambda=0.15406 \mathrm{~nm})$. Scanning electron microscope (SEM, Jeol, JSM6360A) was used for the topographic study, and chemical compositional analysis of $\mathrm{ZnO}$ nanocrystals was carried out using an energy dispersive spectroscope (EDS). Fourier-transform infrared (FTIR, Jasco) spectra were recorded for chemical bonding. Magnetic studies of $\mathrm{ZnO}$ nanocrystals were outlined using vibrating sample magnetometer (VSM). Optical properties were investigated using UV-visible spectrometer (Jasco UV-VIS-NIR, V-670) in the range of 200 to $1000 \mathrm{~nm}$ to determine energy band gap.

\section{RESULTS AND DISCUSSION}

XRD study: XRD patterns of $\mathrm{ZnO}$ nanocrystals are depicted in Fig. 1. The crystal structure of the $\mathrm{ZnO}$ nanocrystals as synthesized by both routes belongs to hexagonal (wurtzite) structure, which is very close with standard JCPDS files (36-1451 and 01-071-6424) [13]. The diffraction peaks were in good agreement with the results reported in the literature [10, 12-14]. In this study, the diffraction peaks were slightly shifted to lower values of $2 \theta$ for $\mathrm{ZnO}$ sample prepared by preparation method II. Shifting of diffraction peaks shows increment in lattice parameters like lattice constants, volume of unit cell, X-ray density, $\mathrm{APF}$ and grain size.

By recording the full width at half maxima (FWHM) of these peaks, the grain size was determined using Debye-
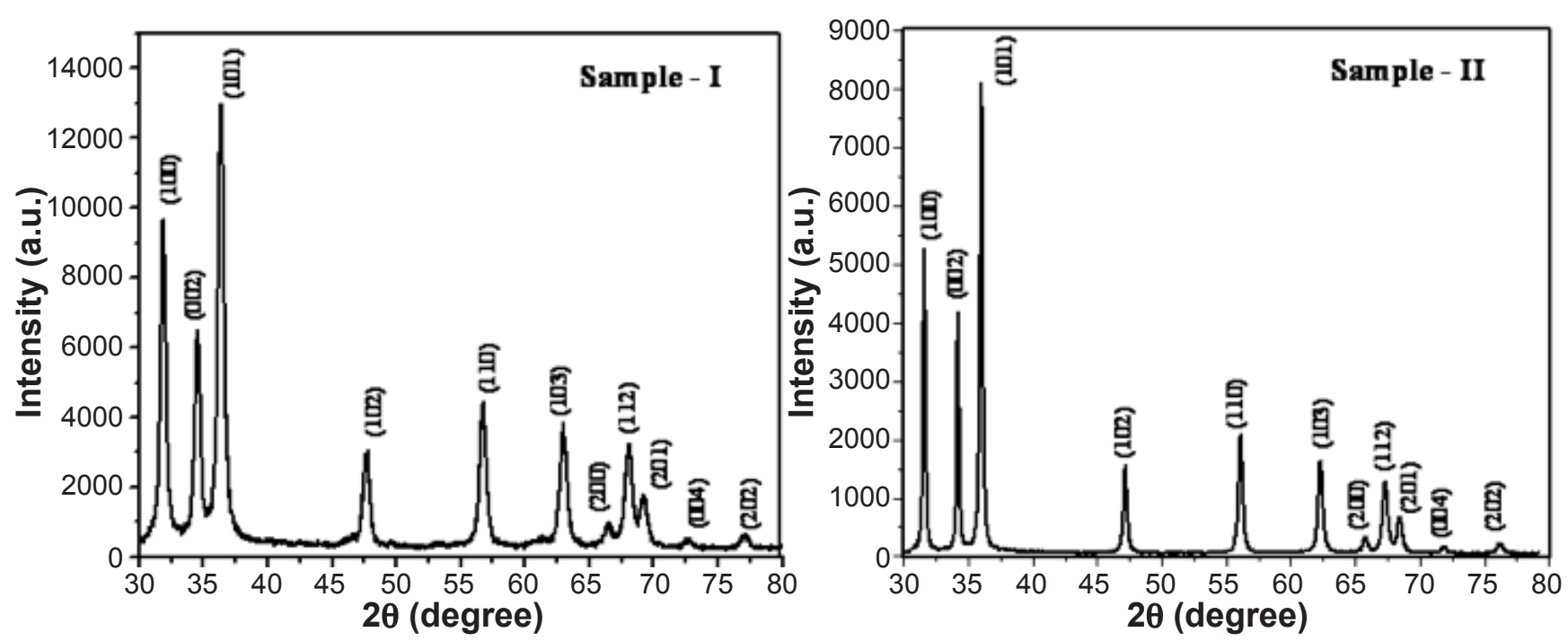

Figure 1: X-ray diffraction pattern for $\mathrm{ZnO}$ nanocrystals synthesized by two precipitation methods.

[Figura 1: Difratogramas de raios X para nanocristais de ZnO sintetizados por dois métodos de precipitação.] 
Scherrer's formula:

$$
\mathrm{D}=\frac{\mathrm{K} \lambda}{\beta \cos \theta}
$$

where $\mathrm{K}$ is the particle shape factor which depends on the shape of the particle and its value is 0.09 for hexagonal particles, $\lambda$ is the wavelength of $\mathrm{CuK} \alpha$ radiation $(0.15406$ $\mathrm{nm}), \beta$ is the full width at half maximum of the selected diffraction peak corresponding to (110) plane and $\theta$ is the Bragg angle obtained from $2 \theta$ corresponding to the same plane. The grain size, lattice parameters, volume cell, X-ray density and atomic packing fraction (APF) of the samples were determined from XRD data and listed in Table I. The lattice constants a and c, volume of unit cell, and grain size of the $\mathrm{ZnO}$ nanocrystals were higher for method II than method $\mathrm{I}$; whereas, X-ray density and atomic packing fraction (APF) values were higher for $\mathrm{ZnO}$ synthesized by method I.

Chemical bonding study: FTIR measurements were performed in the wavenumber range 4000 to $400 \mathrm{~cm}^{-1}$ using $\mathrm{KBr}$ method to confirm the formation of crystalline $\mathrm{ZnO}$ nanoparticles synthesized by precipitation methods I and II as shown in Fig. 2 and to identify absorbed species into the crystal surface. In FTIR absorption spectra of $\mathrm{ZnO}$ nanocrystals synthesized by precipitation route I, broad band was observed around $3380 \mathrm{~cm}^{-1}$ which appears typically due to stretching and bonding modes of hydroxyl $(\mathrm{O}-\mathrm{H})$ group of $\mathrm{H}_{2} \mathrm{O}$ [15]. The additional weak band was detected around $2116 \mathrm{~cm}^{-1}$. The band arising from the absorption of atmospheric $\mathrm{CO}_{2}$ on the metallic cations at $1585 \mathrm{~cm}^{-1}$ [16] and shoulder with asymmetric stretching was detected at around $1010 \mathrm{~cm}^{-1}$. ZnO absorption stretching was observed at around $887 \mathrm{~cm}^{-1}$, and the band at $605 \mathrm{~cm}^{-1}$ is the stretching mode of $\mathrm{ZnO}$ [17]. For the sample synthesized by method II, broad band occurred around $3408 \mathrm{~cm}^{-1}$ which exists due to stretching and bonding modes of hydroxyl $(\mathrm{O}-\mathrm{H})$ group of $\mathrm{H}_{2} \mathrm{O}$. The additional weak band was around 2251 and 2360 $\mathrm{cm}^{-1}$. Band arising from the absorption of atmospheric $\mathrm{CO}_{2}$ on the metallic cations was at $1482 \mathrm{~cm}^{-1}$ and shoulder with asymmetric stretching was detected at around $1222 \mathrm{~cm}^{-1}$. $\mathrm{ZnO}$ absorption stretching was observed at around $938 \mathrm{~cm}^{-1}$, and the band at around $613 \mathrm{~cm}^{-1}$ is the stretching mode of $\mathrm{ZnO}$.

Surface morphology: SEM images of $\mathrm{ZnO}$ nanocrystals are shown in Fig. 3. The image of the $\mathrm{ZnO}$ nano crystals

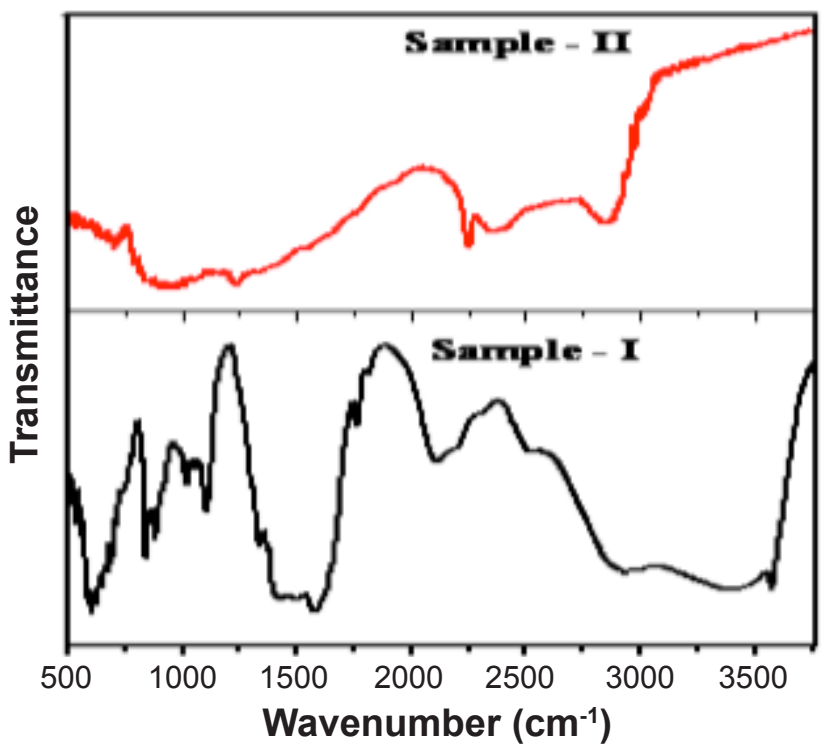

Figure 2: FTIR spectra of $\mathrm{ZnO}$ nanocrystals. [Figura 2: Espectros de FTIR de nanocristais de ZnO.]

prepared by method I shows single morphology like flowery structure and the samples prepared by method II are transparent and crystalline form without aggregation of the particles. This may be due to larger grain size of the particle than that of the particles synthesized by method I. The images show that the synthesized nanoparticles are homogenous, uniformly distributed over the surface. Kumar et al. [18] reported different morphologies obtained for the $\mathrm{ZnO}$ samples calcined at three different temperatures.

Compositional analysis: EDS spectra of the $\mathrm{ZnO}$ nanocrystals are also shown in Fig. 3. Zn and O peaks are observed with no formation of secondary phases. In the sample prepared by method I, a K peak was detected, which may be due to using of $\mathrm{KOH}$ during the synthesis, and a $\mathrm{C}$ peak was observed in the EDS spectrum of $\mathrm{ZnO}$ nanocrystal sample by method II, which may be due to more exposed area of carbon sticker used for the characterization. Platinum peaks were detected in both spectra, which could be due to the platinum coating made at the time of characterization. Kumar et al. [18] also reported that EDS study of $\mathrm{ZnO}$ samples by method II had pure $\mathrm{ZnO}$ phases. From EDS spectra, it was revealed that $\mathrm{ZnO}$ nanoparticles synthesized by method II

Table I - Lattice parameters, X-ray density, unit cell volume, grain size and atomic packing fraction (APF) values of $\mathrm{ZnO}$ nanocrystals.

[Tabela I - Parâmetros de rede, densidade de raios $X$, volume de célula unitária, tamanho de grão e fração de empacotamento atômico (APF) dos nanocristais de ZnO.]

\begin{tabular}{ccccccc}
\hline $\begin{array}{c}\text { Sample code / synthesis } \\
\text { route }\end{array}$ & $\mathrm{a}(\AA)$ & $\mathrm{c}(\AA)$ & $\begin{array}{c}\text { X-ray density } \\
\left(\mathrm{g} / \mathrm{cm}^{3}\right)\end{array}$ & $\begin{array}{c}\text { Volume of } \\
\text { unit cell }\left(\AA^{3}\right)\end{array}$ & $\begin{array}{c}\text { Grain size } \\
(\mathrm{nm})\end{array}$ & $\begin{array}{c}\text { APF } \\
(\%)\end{array}$ \\
\hline $\begin{array}{c}\text { Sample I / precipitation } \\
\text { method I }\end{array}$ & 3.241 & 5.189 & 5.728 & 47.21 & 19.8 & 75.5 \\
$\begin{array}{c}\text { Sample II / } \\
\text { precipitation method II }\end{array}$ & 3.249 & 5.261 & 5.623 & 48.09 & 33.3 & 74.7 \\
\hline
\end{tabular}



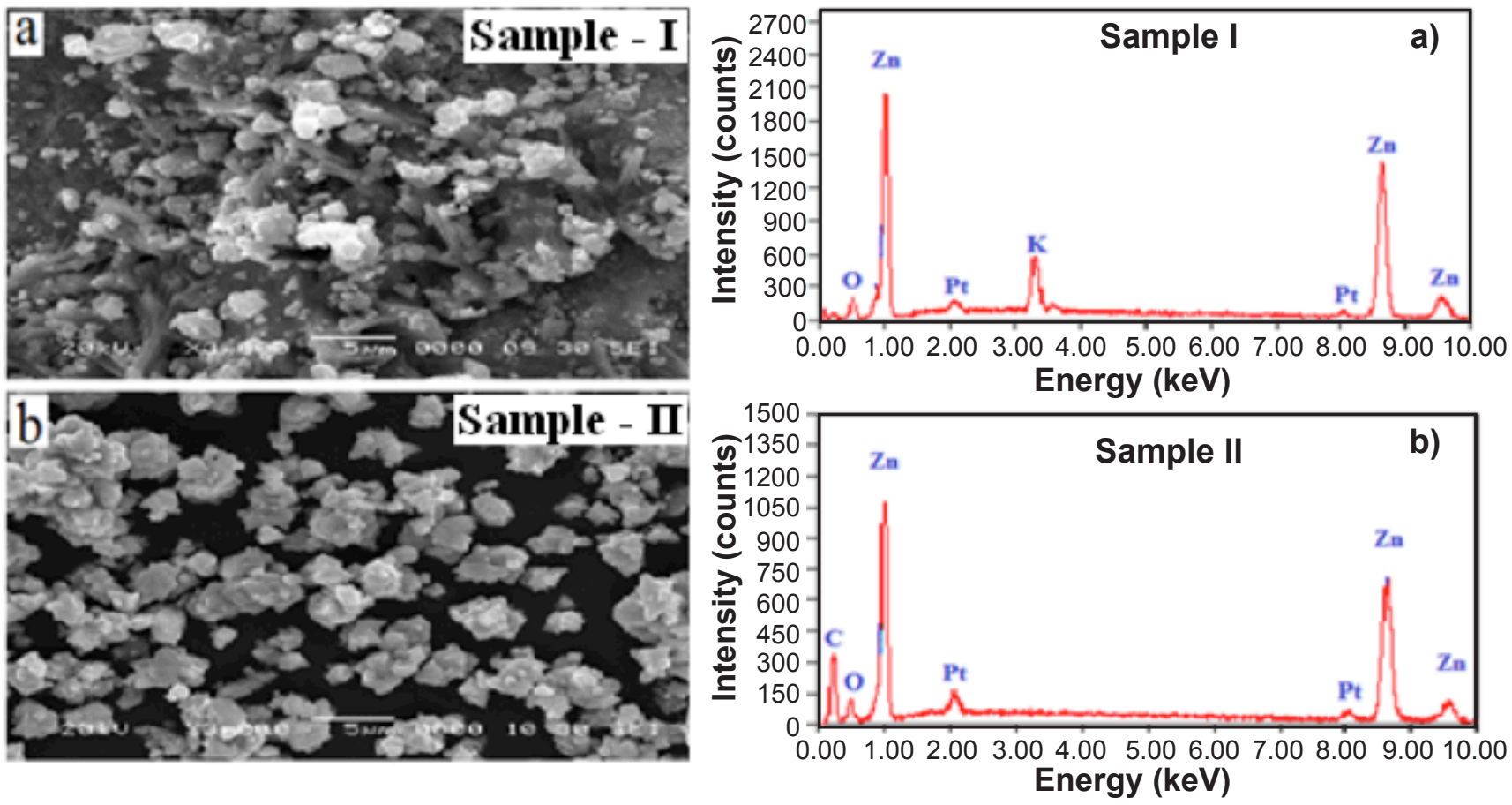

Figure 3: SEM micrographs (left) and EDS spectra (right) of $\mathrm{ZnO}$ nanocrystals.

[Figura 3: Micrografias obtidas por microscopia eletrônica de varredura (esquerda) e espectros de EDS (direita) de nanocristais de ZnO.]

were highly pure, more than that from method I.

TEM study: Fig. 4 shows TEM (transmission electron microscopy) images and SAED (selected area electron diffraction) patterns of $\mathrm{ZnO}$ nanocrystals. Bagabas et al. [19] reported that clear morphology was observed for the calcined samples and not in the case of uncalcined samples. But, it is clearly observed from the images that the particles have hexagonal (wurtzite) structure and average particle size of the nanocrystals synthesized by method I was smaller than the nanocrystals by method II. SAED patterns for $\mathrm{ZnO}$ nanocrystals prepared by precipitation methods I and II are given in the inset of Fig. 4. Mote et al. [20] and Prabhu et al. [14] reported that SAED pattern was not clear with the concentric rings. But in the present investigation, SAED pattern for $\mathrm{ZnO}$ nanocrystals synthesized by method I consisted of eleven sharp and bright concentric rings, which correspond to (100), (002), (101), (102), (110), (103), (200), (112), (201), (004) and (202) diffraction planes of the $\mathrm{ZnO}$ in hexagonal structure and the SAED pattern of $\mathrm{ZnO}$ nanocrystals prepared via method II consisted of six concentric sharp rings, which corresponded to (100), (002), (101), (102), (110), (103) and (112) planes of the $\mathrm{ZnO}$ in hexagonal structure.
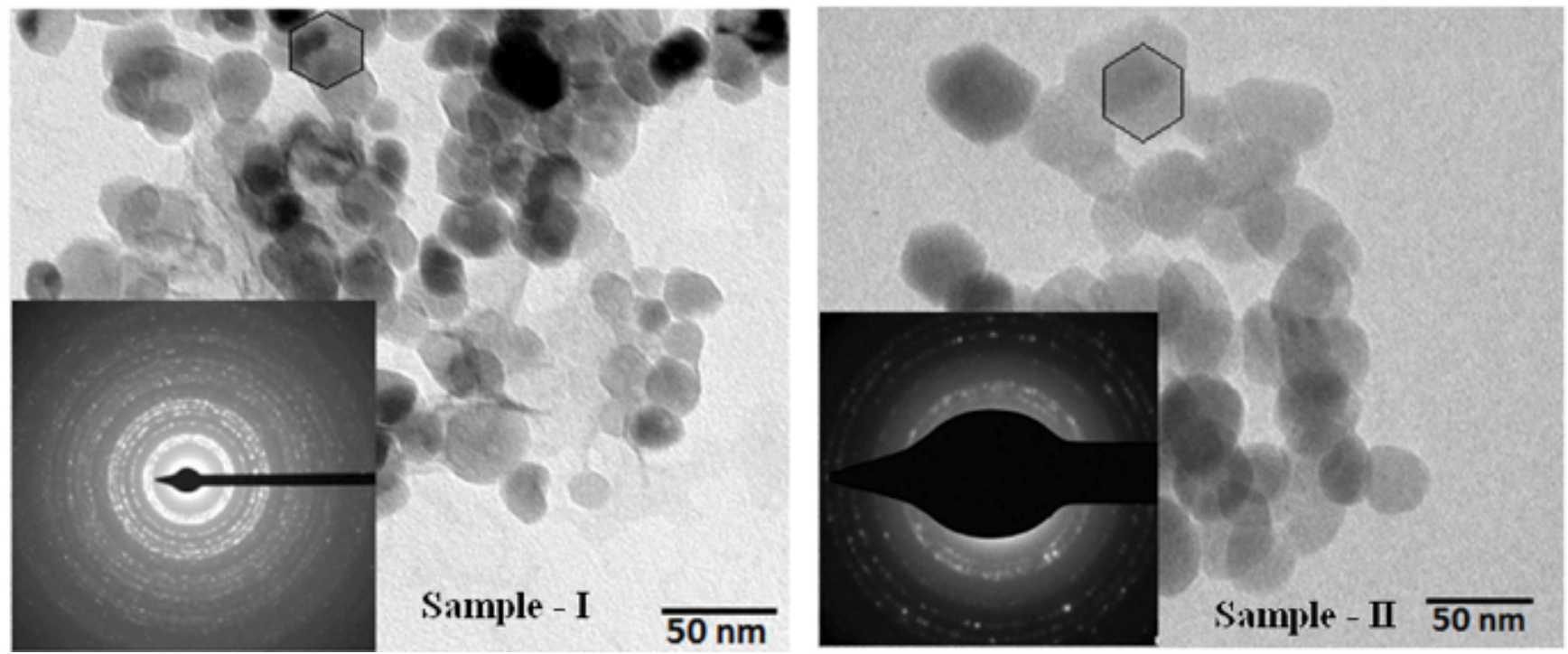

Figure 4: TEM images with SAED patterns for ZnO nanocrystals.

[Figura 4: Micrografias obtidas por microscopia eletrônica de transmissão com padrões SAED para nanocristais de ZnO.] 
Energy band gap estimation: the UV-visible optical absorption spectra of the $\mathrm{ZnO}$ nanoparticles were carried out in the range of 200 to $1000 \mathrm{~nm}$ and are shown in Fig. $5 \mathrm{a}$. Absorption band-edges observed for the nanoparticles of $\mathrm{ZnO}$ synthesized by both methods were around 363 and $361 \mathrm{~nm}$, which is slightly higher than that of the observed value for pure $\mathrm{ZnO}$ nanorods (355 nm) in [21] and less than the reported value $(366 \mathrm{~nm})$ in [22]. Energy band gap of the sample was estimated by following Tauc's equation [23]:

$$
\alpha h v=\mathrm{A}(\mathrm{h} v-\mathrm{Eg})^{\mathrm{n}}
$$

where $\alpha$ is the absorption coefficient, $\mathrm{h} v$ is the photon energy, $\mathrm{A}$ is the constant, $\mathrm{E}_{\mathrm{g}}$ is the energy band gap of the sample. The value of $n$ is $1 / 2$ or 2 depending upon whether the transition from valence band to conduction band is direct or indirect. The value is $1 / 2$ in case of direct transition and 2 in case of indirect transition. Since $\mathrm{ZnO}$ has a direct band structure, the value of $n$ is $1 / 2$ in this case. So, Eq. B becomes:

$$
(\alpha h v)^{2}=\mathrm{B}(\mathrm{h} v-\mathrm{Eg})
$$

where $\mathrm{B}$ is a constant related effective mass of charge carriers associated with valence and conduction bands. Intersection of the slope of $(\alpha h v)^{2} v s h v$ curve provides band gap energy of the samples. The energy band gap was calculated from the absorption plot of energy $(\mathrm{E}=\mathrm{h} v)$ versus $(\alpha \mathrm{h} v)^{2}$ and is shown in Fig. 5b. In the present work, band gaps of $\mathrm{ZnO}$ samples synthesized by precipitation methods I and II were 3.08 and $3.04 \mathrm{eV}$, respectively, which were less than the reported values [22]. Also, they confirmed that $\mathrm{Eg}$ is higher for $\mathrm{ZnO}$ nanocrystals synthesized by method I than II.

Magnetic studies: Fig. 6 shows the M-H plots with field strength up to $1 \mathrm{~T}$ for $\mathrm{ZnO}$ nanocrystals synthesized by precipitation methods I and II. Magnetic study revealed that
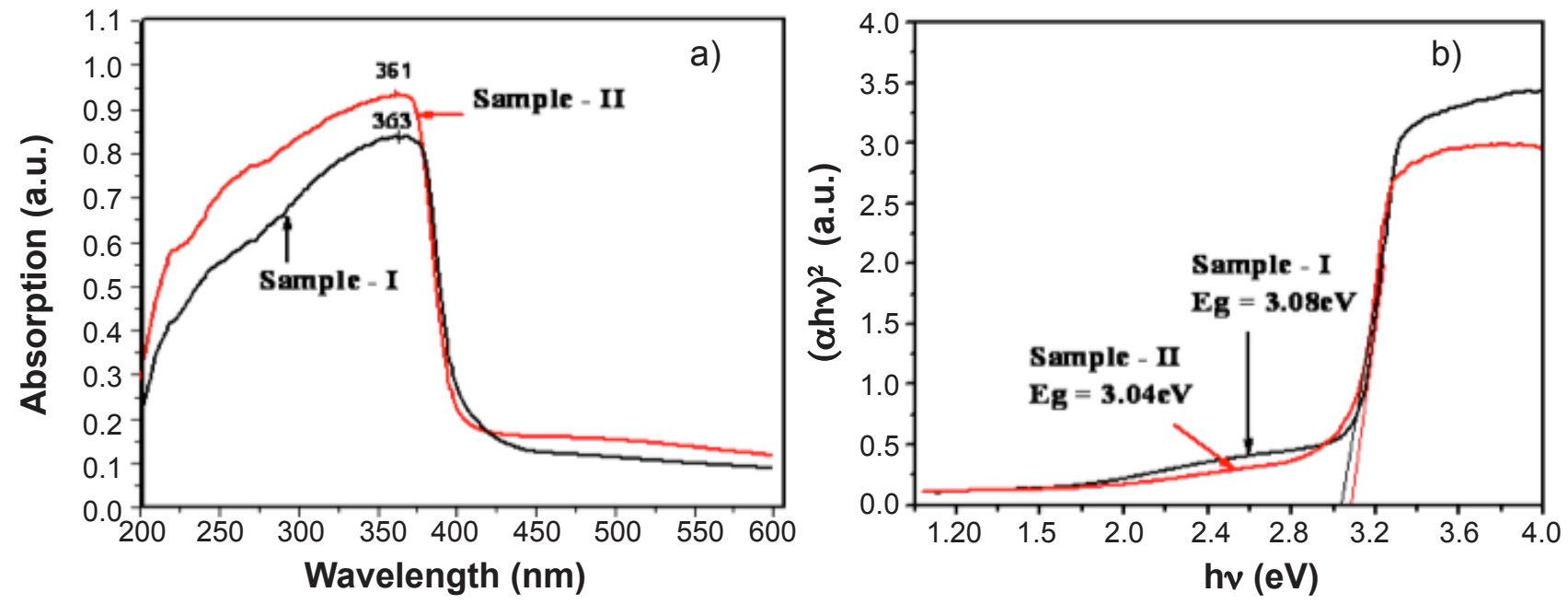

Figure 5: Absorption spectra (a) and Tauc plots (b) for $\mathrm{ZnO}$ nanocrystals.

[Figura 5: Espectros de absorção (a) e gráfico de Tauc (b) para nanocristais de ZnO.]
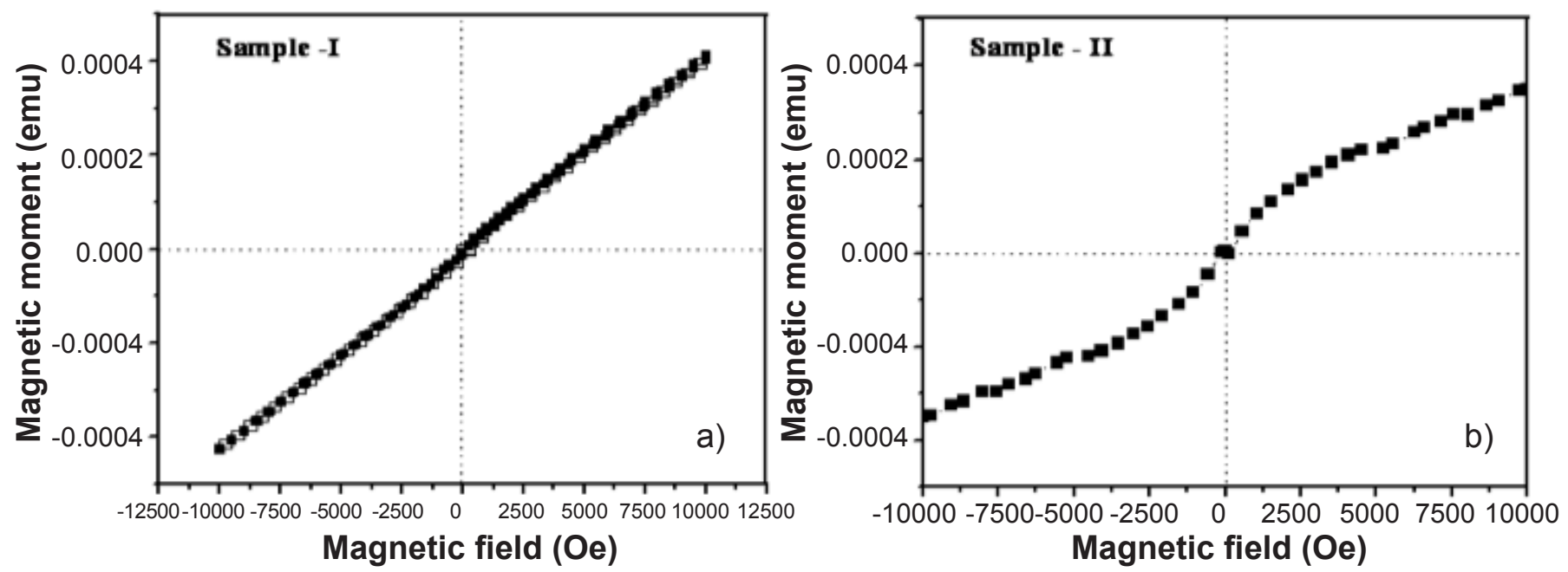

Figure 6: M-H plots of $\mathrm{ZnO}$ nanocrystals.

[Figura 6: Gráficos M-H de nanocristais de ZnO.] 
nanocrystals synthesized by method I showed diamagnetism similar to bulk $\mathrm{ZnO}$. Garcia et al. [24] reported ferromagneticlike contribution for the AMINE- and THIOL-capping agents. But in our study, without using any such capping agents, sample synthesized by method II had ferromagnetic like contribution at room temperature. It implies that magnetic property can be varied from one preparation route to another.

\section{CONCLUSIONS}

Zinc oxide nanocrystals were synthesized by precipitation methods I (zinc acetate dihydrate precipitation with $\mathrm{KOH}$ ) and II (zinc nitrate hexahydrate precipitation with $\mathrm{N}, \mathrm{N}$-dimethylformamide). Hexagonal wurtzite structure was observed from XRD and confirmed by TEM. ZnO nanocrystals synthesized by precipitation method I were found smaller than the nanocrystals synthesized by method II. It was found that $\mathrm{CO}_{2}$ modes were present in the FTIR spectra, may be due to atmospheric $\mathrm{CO}_{2}$ in the samples. The powder prepared by precipitation method I had a potassium contamination which was responsible by the change in the particle growth and $\mathrm{CO}_{2}$ adsorption. Presence of foreign cations during the nanopowder preparation can change the particle growth and the surface properties due to segregation. In this work, the $\mathrm{K}^{+}$has different ionic radius, charge and electronegativity than the host that can promote the surface segregation, and probably change in the surface composition which stabilize the surface and the particle growth. Whereas, in method II, the dimethylformamide is a strong base $\left(\mathrm{pK}_{\mathrm{b}}=3.99\right)$ that promoted the precipitation by $\mathrm{pH}$ change. However, some organic contamination could be involved in the crystallization as shown in the FTIR analysis. Atomic packing fraction was well matched with the standard data. It was confirmed from TEM that the sample prepared by method II was highly crystalline than the nanocrystals synthesized by method I. Number of concentric rings corresponding to the diffraction peaks was higher in the SAED pattern for $\mathrm{ZnO}$ nanocrystals synthesized by method I than II. Energy band gap of $\mathrm{ZnO}$ nanocrystals synthesized by method I was higher than the nanocrystals prepared by method II. $\mathrm{ZnO}$ nanocrystals synthesized by method II showed at room temperature small signature of ferromagnetism. Finally, it was concluded that the sample synthesized by precipitation method I gave better results than method II.

\section{REFERENCES}

[1] X. Zi-Qiang, D. Hong, L. Yan, C. Hang, Mat. Sci. Semi.
Proc. 9 (2006) 132

[2] W. Jun, Y. Yantang J. Mat. Lett. 62 (2008) 1899.

[3] D.P. Norton, M. Ivill, Y. Li, Y.W. Kwon, J.M. Erie, H.S. Kim, K. Ip, S.J. Pearton, Y.N. Heo, S. Kim, B.S. Kang, F. Ren, A.F. Hebard, J. Kelly, Thin Solid Films 496 (2006) 160. [4] D. Wang, C. Song, J. Phys. Chem. B 109 (2005) 12697. [5] P.X. Gao, Y. Ding, W. Mai, W.L. Hughes, C. Lao, Z.L. Wang, Science 309 (2005) 1700.

[6] H. Yu, Z. Zhang, M. Han, X. Hao, F. Zhu, J. Am. Chem. Soc. 127 (2005) 2378.

[7] C. Lu, L. Qi, J. Yang, L. Tang, D. Zhang, J. Ma, Chem. Commun. 33 (2006) 3551.

[8] J.J. Liu, K. Wang, M.H. Yu, W.L. Zhou, J. Appl. Phys. 102 (2007) 024301.

[9] J. Cui, Q. Zeng, U.J. Gibson, J. Appl. Phys. 99 (2006) $08 \mathrm{M} 113$.

[10] U. Manzoor, Md. Islam, L. Tabassam, S.U. Rahman, Physica E 41 (2009) 1669.

[11] R. Bhargava, P.K. Sharma, S. Kumar, A.C. Pandey, N. Kumar, J. Sol. State Chem. 183 (2010) 1400.

[12] Y. Hu, H. J. Chen, J. Nanopart. Res. 10 (2008) 401.

[13] D.K. Bhat, Nanoscale Res. Lett. 3 (2008) 31.

[14] Y.T. Prabhu, K.V. Rao, V.S.S. Kumar, B.S. Kumari, World J. Nano Sci. Eng. 4 (2014) 21.

[15] S. Maensiri, P. Laokul, V. Promarak, J. Cryst. Growth 289 (2006) 102.

[16] J.W. Drazin, R.H.R. Castro, J. Am. Ceram. Soc. 99 (2016) 1105.

[17] K. Nakamoto, Infrared spectra of inorganic and coordination compounds, Wiley, New York (1997).

[18] S.S. Kumar, P. Venkateswarlu, V.R. Rao, G.N. Rao, Int. Nano Lett. 3 (2013) 30.

[19] A. Bagabas, A. Alshammari, M.F.A. Aboud, H. Kosslick, Nanoscale Res. Lett. 8 (2013) 516.

[20] V.D. Mote, Y. Purushotham, B.N. Dole, J. Theor. Appl. Phys. 6 (2012) 6.

[21] M.K. Gupta, N. Sinha, B. Kumar, J. Appl. Phys. 112 (2012) 014303.

[22] R.S. Kumar, R. Sathyamoorthy, P. Sudhagar, P. Matheswaran, C.P. Hrudhya, Y.S. Kang, Physica E 43 (2011) 1166.

[23] A.B. Kashyout, M. Soliman, M. El Gamal, M. Fathy, Mat. Chem. Phys. 90 (2005) 230.

[24] M.A. Garcia, J.M. Merino, E.F. Pinel, A. Quesada, J. de la Venta, M.L.R. Gonzalez, G.R. Castro, P. Crespo, J. Llopis, J.M. Gonzalez-Calbet, A. Hernando, Nano Lett. 7 (2007) 1489.

(Rec. 15/12/2016, Rev. 24/03/2017, 25/04/2017, Ac. 21/06/2017) 